\title{
INTERNATIONAL COURT OF JUSTICE (ICJ) PADA SENGKETA DELIMITASI MARITIM DI PANTAI AFRIKA TIMUR ANTARA SOMALIA DAN KENYA
}

\author{
INTERNATIONAL COURT OF JUSTICE (ICJ) ON MARITIME DELIMITATION DISPUTES ON THE \\ EAST AFRICAN COAST BETWEEN SOMALIA AND KENYA
}

\author{
Karlina Wati Hulu ${ }^{1}$, Stivani Ismawira Sinambela ${ }^{2}$ \\ Universitas Potensi Utama \\ Email: karlinawatihulukarin@gmail.com ${ }^{1}$, vani.sinambela@gmail.com²
}

\begin{abstract}
ABSTRAK
Penyusunan dalam penelitian ini didasari akibat dari terjadinya konflik sengketa maritim antara Somalia dengan Kenya dan masih banyak potensi yang memungkinkan timbulnya sengketa batas laut antara Somalia dengan Kenya. Kedua Negara di Afrika timur itu memperdebatkan 160.000 kilometer persegi wilayah di Samudra Hindia dengan prospek cadangan minyak dan gas yang besar. Sebuah negara pantai berdasarkan aturan internasional, berhak menjamin daerah maritim yang diukur berdasarkan garis pangkalnya, mencakup zona maritim yang sudah diatur pada UNCLOS 1982. Pada 2014 Somalia mengajukan sengketa delimitasi maritim ini ke ICJ (International Court of Justice). Somalia beralasan bahwa garis ukur buat wilayah bahari harusnya sinkron menggunakan arah garis perbatasan 2 negara. Sedangkan Kenya menyatakan bahwa garis ukur perbatasan bahari harusnya ditarik secara horizontal, \& nir menyesuaikan menggunakan arah perbatasan darat ke 2 negara. Penelitian ini menggunakan metode deskriptif kualitatif dengan pendekatan studi pustaka. Untuk dapat melihat bagaimana peran International Court of Justice (ICJ)dalam upaya penyelesaian sengketa delimitasi maritim di kawasan Samudra Hindia. Delimitasi batas maritim antarnegara merupakan penentuan batas daerah atau kekuasaan antara satu negara menggunakan negara lain (tetangganya) pada laut. Pada 2017 Mahkamah Internasional (ICJ) merogoh yurisdiksi buat mengadili konkurensi maritim antara Somalia \& Kenya. ICJ menyatakan bahwa sesudah sidang yang dilakukan, mereka akan membutuhkan ketika kurang lebih 4-6 bulan lagi buat melakukan pertimbangan \& menaruh keputusan atas konkurensi ini. Mundurnya Kenya sebagai satu lagi halangan bagi proses peradilan konkurensi perbatasan ini. Sebagaimana kebanyakan institusi internasional lainnya, ICJ tidak mempunyai prosedur buat memaksa Kenya supaya balik ke prosesi ataupun menjalankan putusannya nanti. Oleh lantaran itu, hal ini masih menyimpan potensi konflik yang akan datang.
\end{abstract}

Kata kunci: International Court Justice, Hukum Laut Internasional, Sengketa Delimitasi Maritim, Afrika Timur

\section{ABSTRACT}

The arrangement in this research is based on the consequences of maritime disputes between Somalia and Kenya and there are still many potentials that allow maritime boundary disputes between Somalia and Kenya to arise. The two countries in east Africa are debating 160,000 square kilometers of territory in the Indian Ocean with the prospect of large oil and gas reserves. A coastal state based on international rules, has the right to guarantee a maritime area measured by its baseline, including maritime zones that have been regulated in UNCLOS 1982. In 2014 Somalia submitted this maritime delimitation dispute to the ICJ (International Court of Justice). Somalia reasoned that the line of measurement for maritime areas should be consistent with the direction of the border line of the two countries. Meanwhile, Kenya states that the maritime border measurement line should be drawn horizontally, and not adjust to the direction of the land border to the two countries. This study uses a 
qualitative descriptive method with a literature study approach. To be able to see how the role of the International Court of Justice (ICJ) in efforts to resolve maritime delimitation disputes in the Indian Ocean region. Delimitation of maritime boundaries between countries is the determination of regional boundaries or power between one country using another country (neighbor) at sea. In 2017 the International Court of Justice (ICJ) entered into jurisdiction to try maritime concurrency between Somalia and Kenya. ICJ stated that after the trial, they will need approximately 4-6 months to consider and make a decision on this concurrency. Kenya's withdrawal is yet another impediment to this border concurrency trial. Like most other international institutions, the ICJ has no procedures to force Kenya to return to the procession or enforce its decisions later. Therefore, this still holds the potential for future conflicts.

Keywords: International Court Justice, International Law of the Sea, Maritime Delimitation Disputes, East Africa

\section{PENDAHULUAN}

Kedaulatan Republik Kenya adalah negara dengan ibu Kota Nairobi terletak di perbatasan Afrika Timur dengan Samudra Hindia, Somalia, Tanzania, Ethiopia, Sudan Selatan dan Uganda, Kenya. Memiliki kondisi dataran rendah dan dataran tinggi dibagi oleh Great Rift Valley. Kenya lebih subur dan beriklim tropis tropical sampai kering. Memiliki kondisi alam tropis dan Kenya dikelilingi oleh pegunungan dan kaya akan sumber daya alam batu kapur, soda abu, garam, permata, fluorit, seng, tanah diatom, gipsum, satwa liar dan tenaga air. Namun, Iklim tropis hingga kering membuat Kenya kekeringan di musim panas dan banjir di musim hujan. Meskipun Kenya sering menderita kekeringan dan banjir, tetapi banyak dataran tinggi Kenya merupakan daerah produksi pertanian paling sukses di Afrika.

Konvensi Hukum Laut 1982 (Joint Konvensi Hukum Laut 1982/ UNCLOS III) digunakan untuk menentukan berapa banyak kekuatan negara di dalam laut teritorial. Secara garis besar, konvensi membagi lautan menjadi dua bagian wilayah laut, yaitu wilayah di dalam dan di luar yurisdiksi nasional. Lainnya di bawah yurisdiksi nasional dibagi menjadi wilayah laut sepenuhnya di bawah kedaulatan suatu negara-negara pesisir dan wilayah laut bagian yang dapat dijangkau oleh negara pantai latihan kekuatan dan hak-hak khusus di bawah Konvensi. Bahkan diberi hak kelola laut, antar negara dipisahkan oleh perairan potensial kontroversi muncul dalam menentukan batas-batas laut antar negara pembatasan.

Banyaknya sengketa wilayah karena saling klaim atas sebidang tanah daerah saat ini menjadi perhatian dunia. Wilayah klaim biasanya dalam bentuk wilayah darat dan laut, tetapi bisa juga berupa pulau-pulau. Secara umum sengketa wilayah dapat disebabkan oleh dua hal, 
yaitu: bentuk gugatan terhadap seluruh negeri, atau bisa juga bentuk mengklaim bagian dari wilayah negara tetangga, Misalnya sengketa wilayah yang akan dibahas dalam artikel ini adalah sengketa wilayah maritim antara Somalia dan Kenya. Memburuknya hubungan Somalia dan Kenya yang memberikan dampak perhatian seluruh komunitas internasional, dan terutama bagian benua Afrika. Sengketa teritorial ini adalah masalah yang sulit untuk dipecahkan dari klaim kepemilikan dapat berkembang menjadi perselisihan yang berakhir dengan konflik dan mengakibatkan buruknya hubungan antar negara yang bersangkutan, bahkan menyebabkan perang.

Hubungan antara Kenya dan Somalia dalam sejarah ketika Mogadishu memutuskan hubungan diplomatik dan menuduh Nairobi mencampuri urusan dalam negerinya. Presiden Kenya Uhuru Kenyatta telah menjadi tuan rumah kepemimpinan politik dari Somaliland, sebuah negara bagian yang memisahkan diri yang tidak diakui oleh pemerintah pusat Somalia. Presiden Somalia Mohamed Abdullahi Mohamed Farmaajo mengusir utusan Kenya ke Mogadishu dan memanggil kembali duta besar negaranya. Kenya secara konsisten membantah ikut campur dan malah mengatakan Farmaajo menggunakannya sebagai kambing hitam untuk mencetak poin politik di dalam negeri ( Krippahl 2021).

Pada saat ini, antara Kenya dan Somalia telah berselisih selama beberapa waktu karena masalah batas ekonomi dan maritim. Tetapi aliansi baru di kawasan itu sekarang memperburuk situasi. Perselisihan terakhir adalah atas dugaan campur tangan Kenya dalam urusan internal Somalia. Negara-negara di Tanduk sedang ditarik ke dalam pertempuran, mengancam akan mengacaukan kawasan yang sudah rapuh. Terlepas dari keterlibatan Otoritas Antar Pemerintah untuk Pembangunan (IGAD) dalam konflik terakhir, badan regional mungkin tidak dapat menyelesaikan masalah sendirian. Krisis tersebut menyerukan tindakan bersama yang kuat oleh Uni Afrika (AU) dan IGAD dengan dukungan mitra internasional, yang berangkat dari keterlibatan AU-IGAD yang biasa. AU harus meningkatkan perannya di kawasan dan mengembangkan strategi dan tindakan nyata untuk menghindari krisis. Kedua negara bertetangga itu terlibat dalam perselisihan mengenai batas laut mereka, dengan keduanya mengklaim sebuah segitiga sempit seluas $100.000 \mathrm{~km}$ persegi yang diperkirakan mengandung simpanan minyak dan gas yang signifikan. Setelah lima tahun upaya oleh keduanya untuk merundingkan kompromi, Somalia akhirnya mengajukan kasus di Mahkamah Internasional 
(ICJ) pada tahun 2014. Kenya \& Somalia mengelilingi 100.000 kilometer persegi Samudra Hindia. Wilayah ini kaya akan asal daya, termasuk ikan, dan mungkin minyak sampai gas alam. Mogadishu sendiri percaya bahwa perbatasan lautnya menggunakan Kenya wajib memanjang pada sepanjang garis tenggara (sama menggunakan perbatasan daratnya). Berdasarkan

penelitian yang telah diuraikan di atas, maka dapat dirumuskan pokok permasalahan yang terjadi antara Somalia dan Kenya sebagai berikut :

\subsection{Rumusan Masalah}

Bagaimana Peran ICJ dalam penyelesaian sengketa delimitasi maritim di Pantai Afrika Timur antara Somalia dan Kenya

\section{TINJAUAN LITERATUR}

\subsection{Hukum Internasional}

Semenjak berakhirnya Perang Dunia II, aturan Hukum Laut merupakan salah satu cabang aturan internasional sudah mengalami perubahan pasca berakhirnya PD II. Bahkan, bisa dikatakan sudah mengalami suatu revolusi yang baru dalam menggunakan perkembangan \& tuntutan zaman. Jika dulu aturan hukum laut inti dalam pokoknya hanya mengurus aktivitasaktivitas pada atas bagian atas bahari, namun dewasa ini perhatian pula sudah diarahkan dalam dasar bahari \& kekayaan mineral yang terkandung di dalamnya. Hukum bahari yang dulunya bersifat unidimensional kini sudah berubah sebagai pluridimensional yang sekaligus merombak filosofi \& konsepsi aturan bahari pada masa lalu.

Secara historis, laut telah terbukti memiliki banyak fungsi di antaranya, sebagai sumber makanan manusia, sebagai jalan raya perdagangan, sebagai sarana penaklukan, sebagai tempat pertempuran pertarungan, sebagai tempat hiburan dan rekreasi dan sebagai alat pemisah. Pengetahuan dan teknologi di berbagai bidang abad ini telah menyebabkan dengan ditemukannya bahan tambang dan peningkatan fungsi laut melakukan penggalian yang berharga di dasar laut dan melakukan segala upaya untuk menggali dan mengeruk kekayaan alam, termasuk permukaan laut dan kekayaan yang ada di dasar laut di bawah. Hukum internasional menyediakan para pihak yang bersengketa dapat menyelesaikan sengketa tersebut sesuai dengan hukum Internasional. 
Dalam beberapa dekade sejak didirikan konsep Majelis Umum Perserikatan BangsaBangsa "common heritage of mankind" pada tahun 1967, International Public Law of the Sea telah melalui proses perubahan yang sangat mendasar dan menyeluruh. Perubahan itu dalam bentuk peningkatan kekuasaan negara lebih dari 200 mil laut dari pantai, peningkatan kekuatan negara pantai atas transportasi kapal yang melewati selat dan kekuatan negara meningkat langkah-langkah perlindungan lingkungan laut. Hukum laut internasional yang belum kedaluwarsa selalu perwujudan supremasi kekuatan maritim Hugo Grotius berdasarkan doktrin "mare liberum" (laut lepas) dengan oleh karena itu, telah mengalami transformasi menjadi seperangkat peraturan hukum yang menggambarkan keseimbangan antara kepentingan nasional negara kelautan dan non laut yang lebih baik.

Hukum internasional adalah norma dan prosedur yang disepakati oleh setiap negara yang telah bergabung dengan Perserikatan Bangsa-Bangsa (PBB). Undang-undang tersebut dirumuskan untuk mengatur kegiatan entitas dalam skala global. Meskipun pada awalnya hukum internasional hanya dipahami untuk mengatur perilaku dan hubungan antar negara, namun perkembangannya kini telah meluas untuk mengatur organisasi internasional, individu, dan perusahaan multinasional. Seperti hal ini yang terjadi konflik dalam ketegangan antara Kenya dan Somalia merupakan kasus hukum internasional yang sedang belum di selesaikan pada beberapa tahun dari ICJ (VOI, 2021). Prof Dr. Mochtar Kusumaatmadja mengungkapkan bila aturan hukum laut internasional merupakan seluruhan kaidah-kaidah \& asas-asas yang mengatur suatu interaksi atau persoalan (yang melintasi) batas-batas negara, antara negara, menggunakan negara.

\section{METODE PENELITIAN}

Penelitian ini merupakan penelitian deskriptif dan kualitatif. Teknik pengumpulan data dilakukan melalui studi kepustakaan dengan data sekunder. Penulis mengumpulkan berbagai dokumen yang berkaitan dengan topik penelitian sebagai bahan referensi penulisan. Dokumen yang dikumpulkan dan dianalisis meliputi buku, e-book, artikel ilmiah elektronik, laporan penelitian, berita Online dan sumber terpercaya lainnya untuk menjawab rumusan pertanyaan tersebut di atas. 
Karlina Wati Hulu, International Court of Justice (ICJ) Pada... 38

\section{PEMBAHASAN}

\section{1 Sejarah Hubungan Somalia dan Kenya}

Setelah pertumbuhan ekonomi Kenya yang semakin membaik, Kenya sendiri memiliki beberapa misi diplomatik dan memiliki. Hubungan bilateral dengan semua negara tetangga dan melakukan kerjasama Ekonomi dan Perdagangan. Kenya dikenal karena hubungan baik dengan negara lain bahkan jika Kenya berkonflik dengan negara tapi Kenya tetap menjaga hubungan baik dengan negara itu sama seperti ketika ada ketegangan di Kenya dengan Sudan dan Ethiopia, Kenya masih mempertahankan hubungan baik dengan Sudan dan Ethiopia. Kenya genap menjadi pusat transportasi dan komunikasi utama di Afrika Timur. Bahkan hubungan antara Uganda dan Tanzania semakin baik penguatan tersebut karena kerja sama mereka di bidang ekonomi. Tidak hanya terkait dengan negara Afrika Kenya ternyata bersahabat dengan negaranegara Barat. Kenya juga bekerja sama dan menjaga hubungan dengan negara Somalia yang merupakan negara tetangga. Mereka berhubungan erat namun secara historis, hubungan mereka sangat tegang karena orang-orang sekelompok etnis Somalia yang telah lama tinggal di tanah yang dimana adanya perbatasan kedua negara tersebut (Motisya, 2017). Kedua negara juga terlibat dalam perseteruan teritorial maritim yang telah berlangsung lama di seberang Samudra Hindia yang diyakini memiliki cadangan minyak dan gas yang berharga.

Hubungan tegang antara kedua negara pada tahun 1963, ketika Somalia memendam klaim bagian dari Distrik Utara Frontier Kenya. Meskipun penandatanganan Perjanjian Arusha terlihat normal kembali, hubungan memburuk lagi ketika Kenya mendukung Ethiopia dalam Perang Ogaden . Namun, kunjungan Presiden Daniel arap Moi ke Somalia pada tahun 1984 membantu meredakan ketegangan. Perang saudara yang berlangsung lama di Somalia memiliki efek limpahan di Kenya. Meskipun demikian, Nairobi mendukung Mogadishu dengan menampung ribuan pengungsinya . Namun, pada tahun 2011, mengutip pertahanan diri terhadap peningkatan serangan lintas perbatasan, Kenya meluncurkan serangan militer ke Somalia untuk mengejar al-Shabaab. Meskipun operasi itu dinodai oleh kontroversi, dengan tentara Kenya dituduh terlibat dalam perdagangan ilegal arang dan gula, diyakini operasi tersebut berkontribusi dalam melemahkan 1-Shabaab dan merebut kembali kota-kota penting, seperti Kismayo. 
Sejak itu, hubungan yang dulunya membaik antara Somalia dan Kenya tidak berlangsung lama di bawah kepemimpinan Siyad Barre yang dimana Somalia mengklaim bahwa wilayah itu didasarkan pada alasan budaya, sejarah dan etnis (Oluoch, 2017). Kemudian, mereka terlibat konflik perbatasan, Kenya tidak terima karena wilayah tersebut di ambil hak milik Somalia yang bukan milik Kenya. Ketegangan hubungan antara kedua tetangga itu semakin meningkat ketika Somalia mengusir duta besar Kenya dari Mogadishu dan memanggil kembali Duta Besarnya dari Nairobi. Namun, pemutusan hubungan diplomatik antara kedua negara tidak berlangsung lama. Konflik yang membuat kedua negara terjadi perselisihan adalah kepemilikan wilayah maritim yang memiliki sumber alam kaya minyak, gas dan tuna di Samudera Hindia yang berada di hadapan Mahkamah Internasional (ICJ). Dalam hal ini, Kenya menolak untuk mengambil bagian dalam mendengar keputusan mahkamahan internasional ICJ Kenya merasa dengan alasan ketidakadilan yang dirasakan bagi negara (ALI, 2021).

\subsection{Perselisihan Sengketa Batas maritim Kenya-Somalia}

Perselisihan yang melibatkan dua negara di benua Afrika tersebut dipicu oleh sengketa perbatasan laut. Baik Kenya dan Somalia memiliki pandangan yang sama tentang perairan teritorial Samudra Hindia. Pada awalnya, Somalia menuduh Kenya memberikan hak eksplorasi sumber daya kepada perusahaan multinasional Total dan Eni di perairan yang disengketakan. Somalia mengajukan tuntutan terhadap Kenya di Mahkamah Internasional pada Agustus 2014. Kedua tetangga Afrika timur itu memperdebatkan 160.000 kilometer persegi wilayah di Samudra Hindia dengan prospek cadangan minyak dan gas yang besar. Perselisihan tersebut berasal dari interpretasi yang saling bertentangan tentang bagaimana batas-batas harus diperluas ke Samudera Hindia . Klaim Somalia adalah bahwa batas selatannya harus membentang ke tenggara sebagai perpanjangan dari perbatasan darat. Pendapat Kenya adalah bahwa perbatasan Somalia harus berbelok kira-kira 45 derajat di garis pantai dan berjalan dalam garis lintang (MALUKI, 2021). Di tengah kontestasi diplomatik antara keduanya, proses pengadilan telah berlangsung selama hampir tujuh tahun. Pada Maret 2020, Kenya mengumumkan bahwa mereka tidak akan lagi berpartisipasi dalam proses pengadilan.

Kenya menyatakan bahwa ada batas laut yang ada yang ditetapkan pada tahun 1979 . Nairobi mengklaim bahwa batas tersebut menempatkan 160.000 kilometer persegi yang disengketakan di dalam wilayah Kenya. Batas itu dihormati oleh kedua negara hingga 2014, 
ketika Somalia membawa Kenya ke Mahkamah Internasional untuk memperdebatkan kepemilikannya. Pemerintah Famajo menentang posisi Kenya ini dan percaya bahwa Somalia hanya bisa mendapatkan keadilan dari Mahkamah Internasional. Kenya juga mempertanyakan komposisi bangku yang menangani kasus tersebut. Hakim Abdulqawi Yusuf, yang merupakan salah satu dari 11 orang yang duduk di bangku cadangan, bukan hanya warga negara Somalia, tetapi juga pernah mewakili Somalia. Pada Konferensi PBB Ketiga tentang hukum laut, Yusuf mengajukan argumen Somalia tentang perselisihan tersebut (MWAKIDEU, 2021). Dalam, penetapan batas zona ekonomi eksklusif Somalia dan landas kontinen tidak boleh dilakukan sesuai dengan prinsip jarak yang sama, melainkan dengan penerapan prinsip-prinsip yang adil. Yang meyatakkan bahwa keputusan yang dibuat harus berpedoman pada kesetaraan dan keadilan tidak harus jarak landas kontinen. Hingga saat ini, Kenya juga mengklaim bahwa ada pihak ketiga dengan kepentingan komersial yang tertarik dengan kasus tersebut. Ia mengklaim pihak-pihak ini mendorong Somalia untuk melanjutkan kasus ini meskipun mengancam akan mengganggu stabilitas perdamaian dan keamanan wilayah yang sudah rapuh.

Pada tahun 2014, Somalia membawa Kenya ke ICJ karena melanggar batas wilayah maritimnya , meskipun ada Nota Kesepahaman (MOU) yang memandu operasi mereka di wilayah yang disengketakan. Meskipun Kenya memprotes ICJ untuk menyelesaikan perselisihan, Somalia mengesampingkan kemungkinan penyelesaian di luar pengadilan. Somalia juga meminta Pengadilan untuk memberikan ganti rugi dari Kenya atas dasar bahwa tindakan negara tersebut di wilayah itu melanggar kedaulatan dan integritas teritorialnya. Pada Februari 2019, Kenya mengumumkan pengusiran duta besar Somalia untuk Kenya dan penarikan duta besar dari Mogadishu dengan klaim bahwa Somalia telah melelang blok minyak di wilayah yang disengketakan. Ini juga memperkenalkan persinggahan wajib untuk pesawat dari Mogadishu. Selain itu, ia mengumpulkan pasukannya dari pedalaman Somalia menuju perbatasan bersama mereka; meninggalkan daerah itu rentan terhadap serangan al-Shabaab . Beberapa bulan kemudian, pada Mei 2019, Kenya menahan delegasi pemerintah Somalia di Bandara Internasional Jomo Kenyatta — yang berada di negara itu untuk menghadiri lokakarya oleh Uni Eropa — karena tidak memiliki visa. Persaingan juga terjadi pada Juni 2020, ketika Somalia mendukung Djibouti alih-alih Kenya untuk kursi anggota tidak tetap Dewan Keamanan PBB. Pada Maret 2020, Somalia melarang impor Miraa/khat dari Kenya menyusul keputusan Nairobi untuk berhenti mengeluarkan visa on arrival ke Somalia . Itu juga mengusir duta besar 
Kenya dari tanahnya setelah Kenya diduga mendukung pemilihan kembali presiden Jubbaland, Ahmed Madobe, yang diyakini berselisih dengan pemerintah pusat.

Hal ini juga menyebabkan pertempuran antara pasukan federal Somalia dan mereka yang setia kepada Madobe, yang meluas ke kota Mandera di Kenya. Selama kunjungan Presiden Somaliland ke Nairobi pada Desember 2020, Kenya berjanji untuk membuka konsulat dan memulai penerbangan langsung ke Hargeisa. Ini tidak berjalan dengan baik dengan Somalia, karena ia terus memiliki klaim atas wilayah tersebut bahkan setelah ia mendeklarasikan kemerdekaannya pada tahun 1991 . Pada tanggal 16 Maret 2021, Kenya menolak untuk mengambil bagian dalam proses lisan di ICJ atas dasar ketidakadilan yang dirasakan oleh Mahkamah, tidak sempat menyiapkan diri mengikuti Covid-19 pandemi, dan mengklaim alam maya sidang tidak cocok. Beberapa pengamat berpendapat langkah ini memberi Somalia sebuah tangan atas karena memiliki banyak waktu untuk berdebat kasusnya. Namun, yang lain berpendapat langkah tersebut berasal dari Kurangnya kepercayaan Kenya di Pengadilan karena kehadiran hakim Ahmed Yusuf, warga negara Somalia di bangku cadangan. Kenya juga percaya Somalia adalah Proxy bagi aktor internasional yang kuat, yang ingin mengisolasinya sehingga memiliki kendali penuh atas Pantai Afrika Timur. Kedua Negara di Afrika timur itu memperdebatkan 160.000 kilometer persegi wilayah di Samudra Hindia dengan prospek cadangan minyak dan gas yang besar. Sebuah negara pantai berdasarkan aturan internasional, berhak menjamin daerah maritim yang diukur berdasarkan garis pangkalnya, mencakup zona maritim yang sudah diatur pada UNCLOS 1982. Pada 2014 Somalia mengajukan konkurensi delimitasi maritim ini ke ICJ (International Court of Justice). Somalia beralasan bahwa garis ukur buat wilayah bahari harusnya sinkron menggunakan arah garis perbatasan 2 negara. Sedangkan Kenya menyatakan bahwa garis ukur perbatasan bahari harusnya ditarik secara horizontal, \& nir menyesuaikan menggunakan arah perbatasan darat ke 2 negara. ( Kontekstual, $2021)$.

\subsubsection{Upaya Penyelesaian Sengketa Delimitasi Maritim pada Mahkamah Internasional}

Penyelesaian konkurensi pada bidang aturan laut sebelum Konvensi Hukum Laut 1982 dilakukan pada kerangka penyelesaian konkurensi internasional dalam umumnya. Dalam hal ini konkurensi aturan bahari diselesaikan melalui prosedur - prosedur \& institusi peradilan internasional yang sudah ada, misalnya Mahkamah Internasional (ICJ). Konvensi Hukum Laut 
1982 sudah menyediakan suatu sistem penyelesaian konkurensi yang sangat kreatif. Dilihat berdasarkan perkembangan sistem peradilan internasional, prosedur Konvensi ini adalah yang pertama kali yang bisa mengarahkan negara-negara peserta mendapat mekanisme memaksa (compuisory procedures ). Dalam hal ini dimana konflik sengketa atas batas wilayah yang dilakukan oleh Somalia maupun Kenya harus dapat di selesaikan agar tidak semakin memperburuk masalah hal tersebut.

Kenya telah menyatakan bahwa mereka lebih memilih untuk menyelesaikan masalah perbatasan di luar pengadilan Putusan ini atas dasar ketidakadilan prosedural di Pengadilan. Ini adalah keputusan yang dibuat setelah refleksi mendalam dan konsultasi ekstensif tentang cara terbaik untuk melindungi kedaulatan dan integritas wilayah Republik Kenya, sementara Somalia ingin kasus itu diadili oleh Mahkamah Internasional (ICJ) (Wabuke 2019 ). Pada bulan Agustus 2014, Somalia mengajukan kasus ke ICJ di Den Haag atas perselisihan sehubungan dengan "pembentukan batas laut tunggal antara dua negara tetangga di Samudra Hindia yang membatasi laut teritorial, zona ekonomi eksklusif, dan landas kontinen di luar 200 mil laut". Somalia menginginkan perbatasan laut berjalan secara diagonal sebagai perpanjangan batas darat sementara Kenya menginginkannya sejajar dengan garis lintang, ke arah timur dan di kota perbatasan Kyunga. Perbatasan maritim menentukan hak eksklusif bagi negara-negara atas sumber daya energi di bawah laut dan setiap perselisihan mengenai garis batas biasanya mendarat di ICJ.

Kenya menegaskan kembali bahwa hal itu tidak pantas di hadapan pengadilan sesuai dengan penerimaannya terhadap yurisdiksi pengadilan. Kenya menggarisbawahi bahwa sementara tidak ada keraguan tentang manfaat kasusnya, ketidakadilan prosedural telah meninggalkan keraguan apakah keadilan substantif akan dilakukan. Kenya kembali menyatakan bahwa seharusnya Somalia tidak diseret ke Pengadilan hanya karena agenda ekspansionis negara tetangga itu. Kenya juga mencatat bahwa komposisi keanggotaan majelis yang melakukan kasus tersebut memperkuat kekhawatiran bias, mengutip kasus Warga Negara Somalia, Hakim Abdulqawi Yusuf, yang duduk di ICJ dan yang sebelumnya mewakili Somalia pada Konferensi Perserikatan Bangsa-Bangsa Ketiga tentang hukum laut.

Selain itu, dalam menegaskan dan memaksakan yurisdiksinya pada Kenya atas masalah ini dan gagal untuk menghargai sepenuhnya keberatan Kenya dalam Deklarasi Klausul 
Opsionalnya di Statuta ICJ, Pengadilan, merampas kesempatan para pihak untuk memiliki perselisihan diselesaikan dengan cara yang sesuai dan tidak bermusuhan, yang sebenarnya telah disetujui sendiri oleh Somalia di bawah Memorandum of Understanding 2009, sebuah instrumen yang telah ditegaskan ICJ sebagai perjanjian yang sah. Kenya juga telah memberi tahu Pengadilan bahwa kepentingan komersial pihak ketiga yang berpengaruh memicu kasus tersebut, yang mengancam akan mengganggu stabilitas perdamaian dan keamanan kawasan yang sudah rapuh. Kecepatan di mana masalah itu dibawa ke Pengadilan dan para pemain yang terlibat dalam perselisihan ini, menunjuk pada strategi yang diatur dengan baik untuk mengadu domba negara-negara satu sama lain dengan mengabaikan situasi keamanan yang genting di wilayah tersebut. Pihak ketiga yang berpengaruh berniat menggunakan ketidakstabilan di Somalia untuk memajukan kepentingan komersial predator dengan sedikit memperhatikan perdamaian dan keamanan di wilayah tersebut.

Kenya telah menganjurkan solusi diplomatik. Preferensi Kenya untuk negosiasi mencerminkan Program Perbatasan Uni Afrika yang mendorong Negara-negara untuk menyelesaikan perselisihan melalui negosiasi bilateral atau dalam arsitektur Perdamaian dan Keamanan Uni Afrika. solusi diplomatik di mana kedua negara dapat membuat penawaran dan penawaran balasan termasuk kemungkinan berbagi sumber daya di wilayah yang diperebutkan. Keindahan diplomasi adalah bahwa banyak kartu dapat dimainkan termasuk perlindungan rezim, masuknya Somalia ke dalam Komunitas Afrika Timur serta akses ke pasar, lembaga akademik atau pembentukan rezim jangka panjang antara kedua negara. Penyelesaian ini juga berhenti akibat melanda pandemi Covid 19 sehingga sampai sekarang belum adanya penyelesaian walaupun di lakukan secara virtual. Namun, Kenya merasa bahwa ada sesuatu ketidakadilan bagi negara Kenya.

Delimitasi batas maritim antarnegara merupakan penentuan batas daerah atau kekuasaan antara satu negara menggunakan negara lain (tetangganya) pada laut. Pada 2017 Mahkamah Internasional (ICJ) merogoh yurisdiksi buat mengadili konkurensi maritim antara Somalia \& Kenya. ICJ menyatakan bahwa sehabis sidang yang dilakukan, mereka akan membutuhkan ketika lebih kurang 4-6 bulan lagi buat melakukan pertimbangan dan menaruh keputusan atas konkurensi atas masalah ini. Mundurnya Kenya sebagai satu lagi halangan bagi proses peradilan konkurensi perbatasan ini. Sebagaimana kebanyakan institusi internasional lainnya, ICJ tidak 
mempunyai prosedur buat memaksa Kenya supaya balik ke prosesi ataupun menjalankan putusannya nanti. Oleh lantaran itu, hal ini masih menyimpan potensi perseteruan yang akan datang. ( Ceanlow,2021 ).

\subsubsection{Dampak Hubungan Bilateral Kenya dan Somalia}

Penarikan Kenya dari kasus tersebut berarti bahwa Kenya tidak lagi mengakui kasus tersebut dan tidak lagi terpengaruh oleh proses persidangan, atau keputusan akhir pengadilan. Pada akhirnya, setiap keputusan yang dibuat oleh Mahkamah Internasional hanya akan dapat dilaksanakan jika kedua pihak yang berkonflik setuju untuk mematuhinya. Ini bisa membawa perselisihan kembali ke titik awal jika Kenya menolak untuk mematuhinya. Dalam hal ini, hanya Dewan Keamanan Perserikatan Bangsa-Bangsa yang memiliki kemampuan untuk menegakkan putusan pengadilan melalui diplomasi koersif. Kemungkinan intervensi Dewan Keamanan dalam masalah ini sangat tipis mengingat penarikan Kenya dari kasus tersebut.

Somalia mengkritik Kenya setelah Kenya memblokir masuknya dua legislator Somalia dan seorang menteri setelah mereka mendarat di bandara Nairobi, dan mulai mendeportasi mereka. Tahun lalu, Kenya menuduh Somalia melakukan "serangan tidak beralasan" di wilayahnya selama konflik antara Somalia dan pasukan regional. Somalia membantah tuduhan itu. Kenya menjadi tuan rumah pemimpin Somaliland, sebuah entitas yang telah mendeklarasikan kemerdekaan dari Somalia sejak 1991 (Explained 2019). Somalia menanggapi dengan menyudahi hubungan diplomatik dengan Kenya, menuduhnya mencampuri urusan dalam negerinya - klaim yang dibantah Kenya. Peristiwa ini memperburuk konfrontasi antara Kenya dan Somalia atas Jubbaland dan membuat Ethiopia dan Kenya berselisih soal Somalia.

Dalam hal ini juga mempengaruhi proses pemilu yang sedang berlangsung di Somalia . Kementerian Luar Negeri Somalia mengatakan dugaan campur tangan Kenya dalam urusan internal Somalia menyebabkan Jubbaland mengingkari perjanjian pemilihan September 2020 . Namun perlu dicatat, bahwa Mogadishu juga berselisih tentang proses pemilihan dengan Puntland, negara bagian federal lainnya. Terlepas dari banyak titik ketidaksepakatan, kedua negara tetap menjadi sekutu dalam perjuangan mereka melawan Al Shabaab, sebuah organisasi teror Islam yang telah meluncurkan beberapa serangan di kedua negara selama dekade terakhir. 


\section{KESIMPULAN}

Setelah pertumbuhan ekonomi Kenya yang semakin membaik, Kenya sendiri memiliki beberapa misi diplomatik dan memiliki. Hubungan bilateral dengan semua negara tetangga dan melakukan kerjasama Ekonomi dan Perdagangan. Kenya dikenal karena hubungan baik dengan negara lain bahkan jika Kenya berkonflik dengan negara tapi Kenya tetap menjaga hubungan baik dengan negara itu sama seperti ketika ada ketegangan di Kenya dengan Sudan dan Ethiopia, Kenya masih mempertahankan hubungan baik dengan Sudan dan Ethiopia. Kenya genap menjadi pusat transportasi dan komunikasi utama di Afrika Timur.

Perseteruan yang melibatkan antara Kenya dan Somalia dalam di benua Afrika tersebut yang dipicu dalam sengketa perbatasan laut. Bagi Kenya dan Somalia memiliki pandangan yang sama tentang perairan teritorial Samudra Hindia. Pada awalnya, Pemerintah Somalia memberikan tudingan terhadap Kenya yang dimana, Kenya memberikan hak eksplorasi sumber daya perairan terhadap perusahaan multinasional. Total dan Eni di perairan yang disengketakan. Somalia mengajukan tuntutan terhadap Kenya di Mahkamah Internasional pada Agustus 2014. Kedua tetangga Afrika timur itu memperdebatkan 160.000 kilometer persegi wilayah di Samudra Hindia dengan prospek cadangan minyak dan gas yang besar. Perselisihan tersebut berasal dari interpretasi yang saling bertentangan tentang bagaimana batas-batas harus diperluas ke Samudera Hindia . Klaim Somalia adalah bahwa batas selatannya harus membentang ke tenggara sebagai perpanjangan dari perbatasan darat

Penyelesaian konkurensi pada bidang aturan bahari sebelum Konvensi Hukum Laut 1982 dilakukan pada kerangka penyelesaian konkurensi internasional dalam umumnya. Dalam hal ini konkurensi aturan bahari diselesaikan melalui prosedur - prosedur \& institusi peradilan internasional yang sudah ada, misalnya Mahkamah Internasional . Konvensi Hukum Laut 1982 sudah menyediakan suatu sistem penyelesaian konkurensi yang sangat kreatif. Dilihat berdasarkan perkembangan sistem peradilan internasional, prosedur Konvensi ini adalah yang pertama kali yang bisa mengarahkan negara-negara peserta mendapat mekanisme memaksa. Dalam hal ini dimana konflik sengketa atas batas wilayah yang dilakukan oleh Somalia maupun Kenya harus dapat di selesaikan agar tidak semakin memperburuk masalah hal tersebut. Kenya telah menyatakan bahwa mereka lebih memilih untuk menyelesaikan masalah perbatasan di luar pengadilan Putusan ini atas dasar ketidakadilan prosedural di Pengadilan. 


\section{DAFTAR PUSTAKA}

\section{Buku}

J.G Starke. Pengantar Hukum Internasional, Jakarta: Penerbit Sinar Grafika. 1992.

Kusumaadmadja, Mochtar. Hukum Laut. Bandung: Bina Cipta, 1978

Mauna, Boer. Hukum Internasional: Pengertian, Peranan dan Fungsi dalam Era Dinamika Global. Bandung. Penerbit: Alumni. 2000.

\section{Jurnal}

Wiratmaja,Gusti, "PENYELESAIAN SENGKETA MARITIME BOUNDARY DELIMITATION DI LAUT KARIBIA DAN SAMUDERA PASIFIK ANTARA COSTA RICA DAN NICARAGUA MELALUI MAHKAMAH INTERNASIONAL",e-Journal Komunitas Universitas Pendidikan Ganesha , No. 1 Vol.,2, 2019,https://ejournal.undiksha.ac.id/index.php/jatayu/article/download/28762/16239

Ika D.P, Angelina, “ Penerapan Hukum Internasional dalam Menghadapi Perompak Somalia ",Digital Repository Universitas Jember , 2015. http://repository.unej.ac.id/handle/123456789/65514

Martinon, Mumma, "KENYA-SOMALIA MARITIME TERRITORIAL DISPUTE: WHY SOMALIA TOOK KENYA TO THE IINTERNATIONAL COURT OF JUSTICE, ADVANTAGES, LIMITATIONS AND EXISTING MODES OF PEACEFUL SETTLEMENT “,Department of Political Science and Public Administration University of Nairobi https://profiles.uonbi.ac.ke/sites/default/files/conniem/files/1. kenya _somalia_territorial_disputes__ _ 21st july 2019 _dr. c.a. mumma-martinon.pdf

Abdikadir, Jamal, “ Kenya Somali Dispute Over Maritime Border Line , 2019 https://www.academia.edu/39718489/KENYA SOMALIA_DISPUTE_OVER MARIT IME BORDER LINE

Chan, K.-. chieh ., 2018. “The ICJ's Judgement in Somalia v. Kenya and Its Implications for the Law of the Sea". Utrecht Journal of International and European Law, 34(2), pp.195-204 https://utrechtjournal.org/articles/10.5334/ujiel.450/

WISMIATI, Fiesta Ayu; KUMALA DEWI, Putu Ratih; WIDYA NUGRAHA, A.A Bagus Surya., 2019," Proses Penyelesaian Sengketa Delimitasi Maritim di Laut Barents Antara Rusia dan Norwegia"Jurnal Hubungan Internasional, Vol.1, No, 1, .https://ojs.unud.ac.id/index.php/hi/article/view/49527/29438

\section{Artikel}

IDN Times, " Kenya Tidak Hadir di Sidang Sengketa Maritim dengan Somalia “, https://www.idntimes.com/news/world/ifan-wijaya/kenya-tidak-hadir-di-sidangsengketa-maritim-dengan-somalia-c1c2( di akses, 16 Maret 2021) 
Tim VOI, " Contoh Kasus Hukum Internasional Terbaru: Sengketa Maritim Kenya an Somalia,https://voi.id/berita/39337/contoh-kasus-hukum-internasional-terbaru-sengketamaritim-kenya-dan-somalia( diakses, 18 Maret 2021)

Antara News, “ Kenya dan Somalia Sepakat untuk Pulihkan Hubungan “, https://m.antaranews.com/berita/1164387/kenya-dan-somalia-sepakat-untuk-pulihkanhubungan( diakses, 15 November 2019)

DW, “ Stability at Risk as Somalia and Kenya spat Over Sea Border ",https://www.dw.com/en/kenya-somalia-border-dispute-threatens-stability/a-56879109 (diakses, 15,03,2021)

ISPI," The Current Crisis in Kenya-Somalia Relations “, https://www.ispionline.it/en/pubblicazione/current-crisis-kenya-somalia-relations$\underline{30360}$ (diakses, 12 May 2021 )

AA, “ Kenya, Somalia stick to Theior Guns as Tensions Soar ", https://www.aa.com.tr/en/africa/kenya-somalia-stick-to-their-guns-as-tensionssoar/2125535 (diakses, 28, 012021 )

Aljazeera," Somalia-Kenya Maritime Boundary Dispute Explained “, https://www.aljazeera.com/amp/news/2021/3/14/somalia-kenya-maritime-disputeexplained ( diakses, 14 Maret 2021

Indian Express, " Explained: The Indian Ocean Border Dispute Between Kenya-Somalia ",https://indianexpress.com/article/explained/explained-indian-ocean-border-disputebetween-kenya-and-somalia-7229569/ ( diakses, 16 Maret 2021 )

BBC News, "Kenya Withdraws from ICJ case over Somalia Sea Border at Last Minute ", https://www.bbc.com/news/world-africa-56391643 ( diakses, 14 Maret 2021)

Africa Arguments, “ Kenya and Somalia's Maritime Dispute: One Winner, Two Losers", https://africanarguments.org/2019/10/kenya-somalia-maritime-dispute-one-winner-twolosers/ ( diakses, 30 oktober 2019)

Ocean Law ," Putusan ICJ di Somalia-Kenya dan Implikasinya terhadap Hukum Laut ",https://www.oceanlaw.org/putusan-icj-di-somalia-v-kenya-dan-implikasinya-terhadaphukum-laut/ ( diakses, 17 June 2021 )

Kontekstual, “ Anggap ICJ bias, Kenya Absen Sidang Sengketa Perbatasan Laut dengan Somalia ",https://kontekstual.com/anggap-icj-bias-kenya-absen-sidang-sengketaperbatasan-laut-dengan-somalia/ ( diakses, 2021 ) 